\title{
Publisher Correction: Regulation of microRNA biogenesis and its crosstalk with other cellular pathways
}

\section{Thomas Treiber, Nora Treiber and Gunter Meister}

Nature Reviews Molecular Cell Biology 20, 5-20 (2019) https://doi.org/10.1038/s41580-018-0059-1

Published online 18 September 2018

The legend of Figure 2 neglected to acknowledge that part $\mathbf{b}$ was adapted with permission from REF. ${ }^{46}$, Elsevier and that part d, third panel from the left was reproduced from REF. ${ }^{62}$, Springer Nature Limited. The change has been made in the HTML and PDF versions of the manuscript.

https://doi.org/10.1038/s41580-019-0106-6 I Published online 6 February 2019

\section{Publisher Correction: Breaking the chains: deubiquitylating enzyme specificity begets function}

\section{Michael J. Clague (1), Sylvie Urbé and David Komander (1)}

Nature Reviews Molecular Cell Biology (2019) https://doi.org/10.1038/s41580-019-0099-1

Published online 07 February 2019

Figure 2 of the article as originally published contained a graphic editing error, whereby the publisher's redrawn figure wrongly indicated the presence of a Drosophila melanogaster orthologue of ZUP1. This has been corrected in the HTML and PDF versions of the manuscript. https://doi.org/10.1038/s41580-019-0112-8 I Published online 19 February 2019 